\title{
The relevance of the no-harm principle to climate change law and politics
}

\author{
Assistant Professor Benoît Mayer \\ Faculty of Law, The Chinese University of Hong Kong
}

\begin{abstract}
Although the no-harm principle has been identified as the cornerstone of international environmental law, it has not generally been recognized as a central feature of international climate change governance. Enduring disagreements as to the relevant normative principles to international cooperation have long plagued international climate change negotiations. This article highlights the general legal and political relevance of the no-harm principle in relation to climate change, including the responsibility of states for breaking this principle. It thus suggests that the climate regime should be framed as a regime recognizing obligations and responsibilities rather than a regime of voluntary participation and assistance. The article includes a detailed account of the reception of the no-harm principle in climate negotiations, a response to three likely objections to the relevance of the no-harm principle, and some reflections on a possible, realistic interpretation of the no-harm principle in relation to climate change.
\end{abstract}

Keywords: no-harm principle, climate change, state responsibility, international environmental law

\section{INTRODUCTION}

Regulation of climate change poses a critical test for the utility and effectiveness of international environmental regulation. ${ }^{1}$

The principle according to which states must ensure that activities within their jurisdiction do not cause significant cross-boundary environmental damage (the 'no-harm' principle) constitutes the cornerstone of international environmental law. ${ }^{2}$ Climate change is certainly the gravest harm that humankind has ever caused to its environment. It may therefore appear counter-intuitive, even surprising, that the no-harm principle has rarely been explicitly invoked in international responses to climate change. ${ }^{3}$

Instead of developing the no-harm principle, the climate regime has largely built upon an ambivalent "principle' ${ }^{4}$ of common but differentiated responsibilities

1. Philippe Sands and Jacqueline Peel, Principles of International Environmental Law (3rd edn, CUP, Cambridge 2012) 239.

2. See reference (n 13).

3. For a meaningful, though isolated, exception, see the Legal Principles relating to Climate Change adopted by the International Law Association in 2014, article 7A. See however discussion in Alexander Zahar, 'Mediated versus Cumulative Environmental Damage and the International Law Association's Legal Principles on Climate Change' (2014) 4 Climate Law 217. 4. A 'principle' suggests a general norm supported by a fundamental reason for action, and it is therefore difficult to consider as a principle, a norm whose very rationale (here, either the capability of wealthy nations, or their 'culpability' as industrial nations) remains disputed. 
(CBDRs). ${ }^{5}$ Yet, recognizing that states have common but differentiated responsibilities '[i]n view of the different contributions to global environmental degradation' ${ }^{6}$ says little about the ground for differentiation or the nature of the responsibility - either the causal responsibility arising from a wrongful act or the moral responsibility of those capable of helping the needy. The adjunct of references to 'equity' and states' 'differentiated capabilities' ${ }^{7}$ does little to clarify how states' individual responsibilities should be conceived. Altogether, the CBDRs principle offers insufficient guidance to international negotiations on climate change; its ambiguity has contributed to the stalemate of climate change negotiations over the last two decades. ${ }^{8}$

The exclusion of the no-harm principle in climate change negotiations is often thought of as the inevitable result of a geopolitical setting where the most influential states are also the highest greenhouse gas emitters. The chancelleries of industrial nations are a priori uninclined to a clear admission of international responsibility as a result of historical or present greenhouse gas emissions, all the more as this responsibility is thought to involve an obligation to make full reparation for any resulting injury. ${ }^{9}$ Yet, a growing engagement of civil society organizations and greater awareness of the dangerous consequences of climate change have already started to erode this denial of responsibility. In the long term, the need to involve emerging and developing nations in global mitigation efforts calls for a more apologetic position from Western nations.

This article is a defence of the relevance of the no-harm principle, including the responsibility of states for breaking this principle, in international responses to climate change. Its focus is on the framing of the climate regime rather than on its substance; it argues that the climate regime should be thought of as a regime recognizing obligations and responsibilities rather than a regime of voluntary participation and assistance. It submits that re-rooting the climate regime in pre-existing international legal principles could give a more consensual basis to international negotiations on climate change and foster popular support for the adoption and implementation of increasingly costly national obligations. This article does not specifically address issues related to the modalities of the no-harm principle to climate change matters, including in particular issues of evidence, causality or valuation of harms.

An intended contribution of this article is to suggest a more realistic interpretation of the no-harm principle and of the obligations of states that follow from a breach of this principle in the context of climate change. In particular, it appears that the remedial obligation of responsible states does not necessarily consist in full compensation, although it

5. See in particular the Rio Declaration on Environment and Development, UN Convention on Environment and Development, principle 7 (1992) [hereinafter 'Rio Declaration']; United Nations Framework Convention on Climate Change (adopted 9 May 1992, entered into force 21 March 1994) 1771 UNTS 107, art 3(1) [hereinafter 'UNFCCC']; Kyoto Protocol to the United Nations Framework Convention on Climate Change (adopted 11 December 1997, entered into force 16 February 2005), 2303 UNTS 148, art 10 (1997) [hereinafter 'Kyoto Protocol']; The Cancun Agreements: Outcome of the Work of the Ad Hoc Working Group on Longterm Cooperative Action under the Convention, decision 1/CP.16, para.1 (2010) [hereinafter 'Cancun Agreements'].

6. Rio Declaration (n 5) principle 7.

7. UNFCCC (n 5) art 3(1).

8. Tuula Honkonen, 'The Principle of Common but Differentiated Responsibility in Post2012 Climate Negotiations' (2009) 18 RECIEL 257; Christopher D Stone, 'Common but Differentiated Responsibilities in International Law' (2004) 98 Am J Int'l L 276, 280.

9. See (n 21). 
certainly demands at the very least a clear acknowledgment of the wrongdoing. This nuanced interpretation, supported by a doctrinal reflection on less-than-full reparation in the law of state responsibility, seems apt to dissipate some of the strongest anxieties that led to the exclusion of the no-harm principle from the climate regime. Accordingly, the no-harm principle would not necessarily require a complete substantial overhaul of the climate regime, but, by providing a more consistent and widely accepted moral justification, reference to the no-harm principle would favour international cooperation beyond the fruitless logic of states' individual interests. This article, however, is not a policy project as such. Further reflection will clearly be needed, by scholars or parties to the policymaking process, on how to implement these ideas in the climate regime.

The rest of the article is organized follows. Section 2 discusses the efforts and objections to applying the no-harm principle to climate change. Then, section 3 develops reflections on the need to adapt the no-harm principle in order to implement it in the specific circumstances of climate change.

\section{APPLYING THE NO-HARM PRINCIPLE TO CLIMATE CHANGE}

This section provides a detailed account of the reception of the no-harm principle in the climate change regime (2.1), before addressing some general objections (2.2).

\subsection{The limited influence of the no-harm principle on the climate regime}

In order to advance peace among nations, general norms of international law were adopted to prohibit any conduct of a state which could cause considerable harms to other states, from which international tensions would be likely to arise. ${ }^{10}$ In particular, the principle according to which states must ensure that activities within their jurisdiction do not cause significant cross-boundary environmental damage ('noharm principle') was first affirmed by the famous Trail Smelter arbitral award of $1941,{ }^{11}$ and re-affirmed by Principle 21 of the 1972 Stockholm Declaration on Human Environment in the following terms:

States have, in accordance with the Charter of the United Nations and the principles of international law, the sovereign right to exploit their own resources pursuant to their own environmental policies, and the responsibility to ensure that activities within their jurisdiction or control do not cause damage to the environment of other States or of areas beyond the limits of national jurisdiction. ${ }^{12}$

Confirmed by countless legal authorities, the no-harm principle has come to constitute the cornerstone of international environmental law. ${ }^{13}$ In its Advisory Opinion

10. See in particular Island of Palmas (1928) II UNRIAA 829 at 839, affirming an obligation of all states 'to protect within the territory the rights of other states, in particular their right to integrity and inviolability in peace and war'; Corfu Channel Case (UK v Albania) [1949] ICJ Rep 4, at 22.

11. United States $v$ Canada (1941) 3 UNRIAA 1905 at 1965.

12. Declaration of the United Nations Conference on the Human Environment, United Nations Conference on the Human Environment, principle 21 (1972) [hereinafter 'Stockholm Declaration']. See also Rio Declaration (n 5) principle 2, which reaffirms principle 21 of the Stockholm Declaration in almost identical terms.

13. For a review, see Sands and Peel (n 1) at 195-200. 
on the Legality of the Threat or Use of Nuclear Weapons, the International Court of Justice identified this principle as customary international law. ${ }^{14}$ Accordingly, the failure of a state to ensure that activities within its jurisdiction do not cause cross-boundary environmental changes entails its international responsibility.

On the other hand, our past and current greenhouse gas emissions are certainly the greatest source of anthropogenic environmental harm ever. Present and foreseeable damages induced by anthropogenic interference with the climate system are unique in their range and scope. In addition to the devastation generated by the increasing frequency of some extreme weather events, ${ }^{15}$ climate change is already affecting in diffuse but undeniable ways - water resources, food production, biodiversity, and possibly human health. ${ }^{16}$ Sea-level rise will also result in loss of territory, challenging the very existence of some low-lying small island developing states. Although the '[g]lobal economic impacts from climate change are difficult to estimate', the International Panel on Climate Change suggested that an increase of the global average temperature by $2^{\circ} \mathrm{C}$ would cause global annual economic losses at a minimum of between 0.2 and 2.0 per cent of global incomes. ${ }^{17}$

Despite the general recognition of the no-harm principle and the cataclysmic harms that climate change will inevitably cause, the influence of the former on the development of responses to the latter has been very limited. Beyond some rhetorical references, ${ }^{18}$ a newly-dedicated academic community has largely approached international climate change law as an autonomous legal field. ${ }^{19}$ Instead of the no-harm principle, the climate regime has built on the basis on the principle of common but differentiated responsibilities, which has been interpreted in two distinct ways. On the one hand, differentiation has been related to the respective historical or current contribution of individual states to climate change. ${ }^{20}$ In this perspective, the CBDRs principle largely builds upon the no-harm principle. On the other hand, however, differentiation has increasingly been construed on the basis of respective capacities. Accordingly, some Western states have accepted a greater moral responsibility as wealthy or

14. Legality of the Threat or Use of Nuclear Weapons (Advisory Opinion) [1996] ICJ Rep 226 [29]: 'The existence of the general obligation of States to ensure that activities within their jurisdiction and control respect the environment of other States or of areas beyond national control is now part of the corpus of international law relating to the environment'. See also Iron Rhine Arbitration (Belgium v Netherlands) (2005), XXVII UNRIAA 35 [222]; Pulp Mills on the River Uruguay (Argentina v Uruguay) [2010] ICJ Rep 14 [101].

15. Simon K Allen et al., 'Summary for Policymakers' in Christopher B Field et al. (eds), Managing the Risks of Extreme Events and Disasters to Advance Climate Change Adaptation (A Special Report of Working Groups I and II of the Intergovernmental Panel on Climate Change) (CUP, Cambridge 2012) 3 at 9.

16. Christopher B Field et al., 'Summary for Policymakers' in Christopher B Field and others (eds), Climate Change 2014: Impacts, Adaptation, and Vulnerability: Volume 1, Global and Sectoral Aspects (Working Group II Contribution to the IPCC Fifth Assessment Report) (CUP, Cambridge 2014) 1 at 4-7.

17. Ibid at 19 .

18. See for instance in UNFCCC (n 5) 8th recital.

19. For an account of the development of climate change law as a new discipline, see Benoît Mayer, 'Climate Change and International Law in the Grim Days' (2013) 24 Eur J Int'1 L 947. 20. See generally Lavanya Rajamani, Differential Treatment in International Environmental Law (OUP, Oxford 2006) 86-8. 
'developed' states, but no specific causal responsibility as industrial states. ${ }^{21}$ This latter interpretation of the CBDRs principle is clearly inconsistent with the no-harm principle.

As a result of developed states' reluctance to admit the relevance of causal responsibility, the climate regime has sometimes inclined towards spontaneous state initiatives - ranging from voluntary funding commitments to the Intended Nationally Determined Contributions - rather than a strict legal regime constituted of rights and obligations as would be suggested by notions of responsibility. Developed states' emission limitation commitments within the Kyoto Protocol were defined not on the basis of their respective historical responsibility, as initially suggested by some developing states, ${ }^{22}$ but on capacity-related criteria, in a quest for the 'least cost way" ${ }^{23}$ to mitigate climate change. The objective of mitigating climate change through 'quantified emission limitation and reduction commitments' ${ }^{24}$ differs in terminology and substance from the obligation of a state responsible for a continuing internationally wrongful act to 'cease that act'. ${ }^{25}$

Likewise, international action on climate change adaptation, which consists mainly in aid projects with a focus on certain environmental issues, contrasts sharply with the restorative obligations of a state responsible for an internationally wrongful act. Although the UN Framework Convention on Climate Change (UNFCCC) requires developed states to 'assist [developing states] that are particularly vulnerable to the adverse effects of climate change in meeting costs of adaptation to those effects' ${ }^{26}$ most of the burden of addressing climate change impacts is still borne by the most affected states. The Warsaw international mechanism for loss and damage associated with climate change impacts established by the parties to the UNFCCC in 2013 continues to face the opposition of developed states to anything reminiscent of restorative obligations and, in fact, to any additional financial instrument. ${ }^{27}$ While the Paris

21. See for instance the statement of the United States on Principle 7 of the Rio Declaration on Environment and Development, in Report of the United Nations Conference on Environment and Development, vol II: Proceedings of the Conference UN Doc A/CONF.151/26/Rev.1 (Vol. II), 17-18 (1992):

The United States understands and accepts that principle 7 highlights the special leadership role of the developed countries, based on our industrial development, our experience with environmental protection policies and actions, and our wealth, technical expertise and capabilities.

The United States does not accept any interpretation of principle 7 that would imply a recognition or acceptance by the United States of any international obligations or liabilities, or any diminution in the responsibilities of developing countries.

22. See in particular the proposal by Brazil, in Additional Proposals from the Parties, Implementation of the Berlin Mandate, UN Doc FCCC/AGBM/1997/Misc.1/Add.3, 7(1997).

23. Proposal by New Zealand, Note by the Secretariat, Proposals from the Parties, Implementation of the Berlin Mandate, UN Doc FCCC/AGBM/1997/Misc.1/Add.1, 5 (1997). For a list of criteria discussed during the negotiation of the Kyoto Protocol, n 5, by Secretariat, Revised Text under Negotiation, Adoption of a Protocol or Another Legal Instrument: Fulfilment of the Berlin Mandate, UN Doc FCCC/CP/1997/2, 31 (1997).

24. Kyoto Protocol (n 5) art 3(1).

25. See in particular Responsibility of States for internationally wrongful acts, articles adopted by the International Law Commission, art 30, reproduced in UNGA Res 56/8 (2001) [hereinafter Articles on State Responsibility].

26. UNFCCC (n 5) art 4(4).

27. See Decision 2/CP.19 (2013) and Decision 2/CP.20 (2014). 
Agreement contains a recognition of the importance of loss and damage and a promotion of action and support, ${ }^{28}$ the decision adopting the Paris Agreement clearly states that this 'does not involve or provide a basis for any liability or compensation' . 29 'Support' with respect to loss and damage remains therefore entirely voluntary.

Further, in order to avoid the embarrassment of opposing power to justice, industrial states have engaged in a strategy of avoiding any principled discussion about climate change. Even in the early negotiations of the UNFCCC, the United States opposed any discussion on the principles that should guide the climate regime. ${ }^{30}$ In 2011, industrial states rejected India's proposal to initiate a dialogue on equity within the UNFCCC. ${ }^{31}$ The following year, the United States seemingly used international aid as a lever to persuade the small island developing state of Palau to stop a campaign seeking a request of the UN General Assembly for an advisory opinion of the International Court of Justice on legal aspects of climate change. ${ }^{32}$

Likewise, industrial states have also strongly opposed the inclusion of a project on the 'protection of the atmosphere' within the long-term programme of work of the International Law Commission, as supported by Special Rapporteur Shinya Murase. From 2011 to 2013, the representatives of industrial states cautioned the International Law Commission against 'interfer[ing] with relevant political negotiations' ${ }^{33}$ about climate change, questioning the Commission's ability to deal with ' $\mathrm{t}] \mathrm{he}$ scientific and technical aspects ${ }^{34}$ of the topic, which, they submitted, 'seemed more suited for discussion among specialists'. ${ }^{35}$ Even though the first implementation of the Kyoto Protocol was coming to an end, they also contended that international climate change negotiations were 'relatively effective' ${ }^{36}$ and had already 'provided sufficient general guidance to states' ${ }^{37}$ If the International Law Commission could eventually initiate this work project, it was at the cost of a political compromise that excluded virtually any important issues from the scope of the topic. ${ }^{38}$

28. Paris Agreement, in Decision 1/CP.21 (2015), art 8.

29. Decision 1/CP.21 (2015), para 52.

30. See eg Daniel Bodansky, 'The United Nations Framework Convention on Climate Change: A Commentary' (1993) 18 Yale J Int'l L 451, 501.

31. UNFCCC, Report of the Conference of the Parties on its seventeenth session, held in Durban from 28 November to 11 December 2011, Part One: Proceedings, UN Doc FCCC/CP/2011/9, paras 13-18 (2011).

32. See eg Stuart Beck and Elizabeth Burleson, 'Inside the System, Outside the Box: Palau's Pursuit of Climate Justice and Security at the United Nations' (2014) 3 Transnat'l Envtl L 17, 26.

33. Petr Válek, Czech Republic, in the summary record, 18th meeting of the Sixth Committee of the UN General Assembly's 68th session, UN Doc A/C.6/68/SR.18, para 102 (2013). See also eg Andrea Tiriticco, Italy and Todd Buchwald, United States, in the summary record, 19th meeting of the Sixth Committee of the UN General Assembly's 68th session, UN Doc A/C.6/68/SR.19, paras 10, 118 (2013).

34. Ms. Belliard, France, in the summary record, 19th meeting of the Sixth Committee of the UN General Assembly's 67th session, UN Doc A/C.6/67/SR.19, para 91 (2012).

35. Ms. Noland, Netherlands, in the summary record, 28th meeting of the Sixth Committee of the UN General Assembly's 66th session, UN Doc A/C.6/66/SR.28, para 64 (2011).

36. Mark Simonoff, United States, in the summary record, 20th meeting of the Sixth Committee of the UN General Assembly's 66th session, UN Doc A/C.6/66/SR.20, para 15 (2011).

37. Todd Buchwald, United States, in the summary record, 19th meeting of the Sixth Committee of the UN General Assembly's 67th session, UN Doc A/C.6/67/SR.19, para 118 (2012). 38. See Shinya Murase, First report on the protection of the atmosphere, UN Doc A/CN.4/ 667, para 5 (2014), including the following condition (among others): 'Work on this topic will proceed in a manner so as not to interfere with relevant political negotiations, including 
The uprooting of climate governance from the no-harm principle has caused a lack of normative foundations which could serve as an objective touchstone for the reasonableness of national claims. This lack of normative foundations, in turn, has left room for the development of relatively improbable alternative academic and political discourses, attempting for instance to frame climate change as an indirect threat to the enjoyment of human rights, ${ }^{39}$ or on the basis of states' self-interests. ${ }^{40}$ Yet, the fact that climate change hinders the effective enjoyment of human rights provides little general guidance in devising international cooperation on climate change mitigation, while a state pursuing its self-interest is likely to try to free-ride on others' efforts rather than earnestly participate in efforts to mitigate climate change. ${ }^{41} \mathrm{~A}$ comprehensive ethical narrative supporting international cooperation against climate change and its adverse effects requires more than a vague reference to the impacts of climate change on human rights, and more than an analysis of states' self-interests.

\subsection{The continuing normative relevance of the no-harm principle}

A breach of the no-harm principle can be invoked when three conditions are met: (1) a cross-boundary environmental damage; (2) a causal relation with specific activities within the jurisdiction of a state; (3) the failure of this state to take reasonable measures to prevent the harm. ${ }^{42} \mathrm{~A}$ breach of the no-harm principle entails secondary obligations for the responsible state.

When applied to the context of global anthropogenic climate change, each of these elements raises plenty of technical issues. On the one hand, the contours of the noharm principle are not clearly determined. On the other hand, climate change raises delicate issues with regard to the definition of secondary obligations in case of a breach, given the concomitant responsibility of multiple states, the scattered and indirect nature of the resulting harm, and the high complexity of the relation between greenhouse gas emissions and such harms. Nevertheless, there seems to be no good reason to deny the applicability of the no-harm principle, at the most fundamental and abstract level of analysis, for excessive greenhouse gas emissions, at least in the case of industrial states that have patently been failing to take any measures to reduce these emissions within their jurisdiction since the discovery of anthropogenic causes of climatic change several decades ago.

In support of this position, the three most probable objections to the relevance of the no-harm principle to international responses to climate change are addressed: the

those on climate change, ozone depletion, and long-range transboundary air pollution. The topic will not deal with, but is also without prejudice to, questions such as the liability of States and their nationals, the polluter-pays-principle, the precautionary principle, common but differentiated responsibilities, and the transfer of funds and technology to developing countries, including intellectual property rights'.

39. See eg Cancun Agreements (n 5) 7th recital; and the 'Geneva Pledge for Human Rights in Climate Action' (13 February 2015), signed by representatives of 18 states.

40. See Eric A Posner and David A Weisbach, Climate Change Justice (Princeton University Press, Princeton 2010).

41. Posner and Weisbach elude this question by claiming that states have a moral duty not to free-ride a Pareto-optimal treaty. This claim goes directly against their preliminary rejection of morality as relevant guidance for the climate regime. See Posner and Weisbach, ibid, at 183. 42. See in particular the references cited (nn 12-14). See also ILA (n 3) art 7A; B Mayer, 'State Responsibility and Climate Change Governance: A Light through the Storm' (2014) 13 Chinese JIL 539; Christina Voigt, 'State Responsibility for Climate Change Damages' (2008) 77 Nordic JIL 1. 
lex specialis objection; an objection to the collective and historical responsibility; and an objection to the political opportunity of the no-harm principle.

\subsubsection{The lex specialis objection}

A first possible objection is that any responsibility of states for a breach of the noharm principle is precluded by the development of specific norms dealing with the same matter within the climate regime. One might accordingly argue that the CBDRs principle excludes the applicability of the no-harm principle to climate change matters, or that the Kyoto Protocol 'functions as a kind of lex specialis that displaces' the application of the no-harm principle. ${ }^{43}$

For the lex specialis principle to apply, however, 'it is not enough that the same subject matter is dealt with by two provisions; there must be some actual inconsistency between them, or else a discernible intention that one provision is to exclude the other' ${ }^{44}$ There seems to be no discernible intention in climate change agreements to exclude the application of the general law of state responsibility. On the contrary, in fact: small island developing states have made a series of statements to establish that their participation in the climate regime does in no way "constitute a renunciation of any rights under international law concerning state responsibility for the adverse effects of climate change, and that no provisions in the Convention [could] be interpreted as derogating from the principles of general international law'. ${ }^{45}$ The climate regime aims, perhaps, at mitigating the injury, but not at addressing the responsibility of states for a breach of the no-harm principle; as such, it does not constitute a lex specialis. ${ }^{46}$

But even if the climate regime did constitute a lex specialis, the no-harm principle could remain relevant to political negotiations, if not directly applicable through the courts. Establishing that different rules apply does not suffice to justify this derogation to a general legal and moral principle.

\subsubsection{The objection to collective responsibility}

Another objection to the applicability of the no-harm principle with regard to climate change is based on normative grounds. Eminent lawyers such as Eric Posner and David Weisbach dismissed the moral relevance of collective responsibility in this context on the ground that it would produce unfair results in certain individual situations: in their example, some Indians may have a greater individual responsibility than some Americans. ${ }^{47}$ In a similar vein, Alexander Zahar asked rhetorically:

Given that responsibility for [climate change] rests with people, where does the legal responsibility of states to address the causes and impacts of climate change come into the picture? I would say that it does not, at least not automatically. ${ }^{48}$

43. Zahar (n 3) 230.

44. See Articles on State Responsibility (n 25) commentary under art 55, para 4.

45. Declarations of Kiribati, Fiji, Nauru and Tuvalu upon signature of the UNFCCC, 1771 UNTS 317-18.

46. B Mayer, 'The Applicability of the Principle of Prevention to Climate Change: A Response to Zahar' (2015) 5 Climate Law 1 at 15.

47. Posner and Weisbach (n 40) at 106. Other conceivable arguments could be that the responsibility of corporations is more relevant than that of states. In general, however, arguments seeking corporate responsibility do not exclude state responsibility as an alternative way to do justice.

48. Zahar (n 3) at 218. 
It is noteworthy that neither Alexander Zahar, nor Posner and Weisbach suggest any realistic avenues for international governance to deal with individual responsibilities. Conceiving individual responsibilities in relation to climate change would raise a range of intractable practical issues - much greater than those, themselves very significant, raised by state responsibility. ${ }^{49}$ Individual greenhouse gas emissions are largely influenced by path dependence - for instance by political decisions to invest or not in public transportation. Moreover, individuals benefit from the emissionsintensive activities of other individuals, not only through direct commercial interactions, but also by inheriting living conditions that relate to remote historical emissions. It is practically impossible to establish concrete mechanisms to address past or present excessive greenhouse gas emissions in individual terms, and even forward-looking individual incentives to reduce emissions, such as carbon taxes, tend to elude the relevance of collective choices.

But whether or not there is any alternative, such summary dismissing of collective responsibility is inconsistent with the contemporary architecture of international law. Any idea of collective obligation assumes the possibility of collective responsibility, and existing international law - as still mostly a law applicable to sovereign states - is based on a recognition that collective obligations is a practical and morally acceptable way of addressing global concerns. Therefore, a consistent argument against collective responsibility in the context of climate change should inevitably extend to a critique of the concept of sovereign states as an institution regulating the relation of different populations. ${ }^{50}$ In the existing international legal regime, it would be arbitrary to reject state responsibility in relation to climate change without changing the premises of international law altogether.

The no-harm principle and the responsibility of states for internationally wrongful acts constitute indispensable features of today's international governance. In order to remain equal and sovereign, states must respect one another's sovereignty. ${ }^{51}$ In a world where technological progress has established multiple channels through which a state's intentional conduct or mere negligence can significantly affect the environment of others, some regulation of cross-boundary environmental damages has to be maintained. ${ }^{52}$ As a matter of fact, the wording of Principle 21 of the Stockholm Declaration and Principle 2 of the Rio Declaration reflects the necessary relation between the sovereign right of states to exploit their resources and their responsibility to ensure that activities within their jurisdiction do not infringe the enjoyment of the

49. B Mayer, 'Whose "Loss and Damage"? Promoting the Agency of Beneficiary States' (2014) 4 Climate Law 267.

50. For such a consistent argument against the contemporary concept of the state, see Philip Allott, 'State Responsibility and the Unmaking of International Law' (1988) 29 Harv Int'l LJ 1, $13-26$.

51. See, generally, references cited (n 10).

52. By contrast, a different rule was possible in a world that was little industrialized, and perhaps necessary when states generally assumed less control over their citizens. Before the Trail Smelter case, the Harmon doctrine contended that, due to its absolute territorial sovereignty, any state could engage in or permit whatever activities, regardless of their consequences on the environment of other states. Even then, however, state practice was inconsistent with the Harmon doctrine. See discussion in Stephen C McCaffrey, 'The Harmon Doctrine One Hundred Years Later: Buried, Not Praised' (1996) 36 Nat Resources J 549. See also Clyde Eagleton, The Responsibility of States in International Law (New York University Press, New York 1928) 80, stating in unambiguous terms that '[a] State owes at all times a duty to protect other States against injurious acts by individuals from within its jurisdiction'. 
same right by other states. ${ }^{53}$ Likewise, responsibility for a breach of an obligation is an indispensable component of any legal regime. As the Permanent Court of International Justice noted in the Chorzów Factory case, 'it is a principle of international law, and even a general concept of law, that any breach of an engagement involves an obligation to make reparation'.54

\subsubsection{The objection of political opportunity}

A last possible objection to the relevance of the no-harm principle relates to its political feasibility and opportunity. This objection purports that the no-harm principle is fundamentally inapt to address the issue of climate change because of the existence of formidable political obstacles. How could justice be done in a world dominated by politics?

Indeed, international litigation seeking the responsibility of states on the ground of their failure to limit greenhouse gas emissions within their jurisdiction would face formidable obstacles. Because of unspecific difficulties such as the consensual nature of international litigation, ${ }^{55}$ very few cases regarding the breach of the no-harm principle have been decided by international courts or tribunals altogether (although the spectre of litigation has facilitated the friendly resolution of some cases) ${ }^{56}$ Additional difficulties result from the greater diplomatic power of states that have emitted or are emitting most greenhouse gases, as compared to the states most severely affected by climate change. The concomitant responsibility of multiple states (although to very different degrees) and the distribution of harm among all states is yet another difficulty. ${ }^{57}$ No court appears to have sufficient political legitimacy to set a precedent and to persuade states to implement its decision, with tremendous consequences for the climate regime. ${ }^{58}$

53. Stockholm Declaration (n 12) principle 21; Rio Declaration (n 5) principle 2.

54. Chorzów Factory (Germany v Poland) (Merits) PCIJ, Ser. A No 17, 47 (judgment of 13 September 1928).

55. See eg Statute of the International Court of Justice, 33 UNTS 993, art 36 (1946).

56. At least two cases of environmental harms brought before the International Court of Justice - Certain Phosphate Lands in Nauru (Nauru v Australia) and the case of Aerial Herbicide Spraying (Ecuador v Colombia) - were discontinued when the parties reached a friendly agreement.

57. According to the Monetary Gold principle, the International Court of Justice has refused to determine the responsibility of an individual state if, in order to do so, it would have to rule, as a prerequisite, on the lawfulness of the conduct of a third state not party to the dispute. See Monetary Gold Removed from Rome in 1943 (Italy v France) [1954] ICJ Rep 19, 32; East Timor (Portugal v Australia) [1995] ICJ Rep 90, [35]; Certain Phosphate Lands in Nauru (Nauru v Australia) (Preliminary Objections) [1992] ICJ Rep 240, 259-60. See however Alexander Orakhelashvili, 'Division of Reparation between Responsible Entities', in James Crawford et al. (eds), The Law of International Responsibility (OUP, Oxford 2010) 664, arguing, partly contra legem, that 'the doctrine of the absent third party must not be allowed to preclude the judicial enforcement of responsibility for the entire category of actions and wrongful acts, namely the wrongs committed by more than one State, whether through a joint action, joint organs, complicity, or direction or control'.

58. By analogy (in a domestic legal regime), see for instance Native Village of Kivalina $v$ ExxonMobil Corp (appeals), 663 F.Supp.2d 863, at 858 (ND Cal 2009), stating that 'the solution to Kivalina's dire circumstance must rest in the hands of the legislative and executive branches of our government, not the federal common law'. 
Norms of international law may however influence global politics even when judicial proceedings are unlikely. This is perhaps most obviously the case when states' constituencies adhere to certain ideas of appropriateness, through bottom-up demands for compliance rather than a top-down constraint of enforcement. The principle that a state bears responsibility for its failure to ensure that activities within its jurisdiction do not cause cross-boundary environmental damage, being an indispensable element of existing international institutions, reflects and reinforces moral conceptions widely accepted by the international community. In the absence of a jurisdictional enforcement mechanism, there is a legitimate claim for political negotiations to seek to implement such a principle and, possibly, genuine democratic support for this position even within industrial nations, fuelled by growing awareness of the need to fight climate change.

One might object to this on the grounds that invoking the no-harm principle and state responsibility could hinder international negotiations through unrealistic demands for compensation. ${ }^{59}$ But the opposite might also be true: that the development of unrealistic claims for reparation results from a lack of thorough engagement with climate change through the lenses of the no-harm principle. It is a central claim of this article that a nuanced interpretation of state responsibility in relation to climate change is possible, and that such an interpretation would contribute to overcoming existing political obstacles. The no-harm principle does not necessarily require responsible states to make full reparations, although it does require at least an unconditional acknowledgment of wrongfulness. Meanwhile, the outright rejection of any reference to the no-harm principle and the denigration of its advocates as 'extremists' ${ }^{60}$ have also contributed to fuelling unrealistic expectations in Western societies. As the share of greenhouse gas emissions originating from the developing world is rapidly increasing and no complete mitigation regime appears possible without the participation of emerging economies, substantial concessions will be needed on both sides.

\section{ADAPTING THE NO-HARM PRINCIPLE TO CLIMATE CHANGE}

The exclusion of references to the no-harm principle in responses to climate change seemingly follows from a misunderstanding. It is often assumed that this principle would necessarily prescribe unrealistic objectives, in particular an obligation of industrial states to cover all the expenses that could be attributed to the adverse impacts of climate change in developing states. However, even though such arguments could be made on the basis of the no-harm principle, they do not necessarily follow from the affirmation of the no-harm principle.

A principle can generally be understood as a 'guide to action' ${ }^{\prime 61}$ rather than a detailed set of rules that dictate all aspects of a conduct. By necessity, interpreting a principle when responding to a novel matter requires a certain measure of creative thinking, recognizing the strengths but also the limitations of analogies with previous cases where the principle was applied. Despite this difficulty, re-rooting international responses to climate change in a consistent interpretation of the no-harm principle

59. This was one of the arguments opposed to the International Law Commission's project on the protection of the atmosphere. See in particular the statement of Petr Válek (n 33).

60. Statement of Senator Byrd, in Byrd-Hagel Resolution (25 July 1997) 143 Cong Rec S8138, 8117.

61. Oxford English Dictionary, 'principle', definition 4(a). 
could facilitate international negotiations by defining a common frame of reference and by building shared expectations or, at least, by precluding certain arbitrary claims.

A source of flexibility in interpreting the no-harm principle in relation to climate change can be found within existing rules of international law (intra legem). Relevant rules range from the limitation of states' due diligence obligation under the no-harm principle, to the recognition of certain circumstances precluding wrongfulness, such as necessity. Yet, other issues need to be addressed in the silence of the law (praeter legem), on equitable grounds. Many important modalities of the no-harm principle have remained undetermined as a result of the customary nature of the no-harm principle $^{62}$ and of the limited number of jurisdictional decisions. For instance, there is no determinative authority to define the geographical scope of states' obligation under the no-harm principle, although analogies can be drawn from other fields, in particular international human rights law.

Last but not least, it cannot be excluded that some modalities of the no-harm principle, although clearly defined, could be revealed as clearly unfit to respond to climate change. Such circumstances could justify an interpretation of the no-harm principle in contradiction with existing rules (contra legem). This is perhaps the case regarding the secondary obligation of a responsible state to make full reparation, a rule clearly recognized in the law on the responsibility of states for internationally wrongful acts, but whose consequences seem excessive in the circumstance where culpable negligence causes widespread environmental damage. However, even in this case, there appears to be sufficient analogous state practice to deny that the general character of the obligation is to make full reparation. From war reparations to investment disputes, states have often accepted derogations to the obligations to make full reparation in order not to place excessive demands on responsible states.

Following subsections discuss necessary adaptations or refinements of the obligations of states arising from the no-harm principle: their primary obligations (1), their obligation to cease a continuing breach of the principle (2), and their remedial obligations (3).

\subsection{Primary obligations}

When conceiving the no-harm principle in the context of climate change, difficulties arise mainly in two respects: as to the nature of the harm and as to the content of states' obligations.

\subsubsection{The nature of the harm}

The existence of a harm or injury is relevant at the stage of determining a breach of the no-harm principle and, then, at the stage of assessing the content of restorative obligations. Some wordings of the no-harm principle suggest that it only applies in the presence of serious harms, ${ }^{63}$ but such a requirement should not pose difficulties

62. See Chritina Voigt, 'Book Review (Climate Change Damage and International Law: Prevention Duties and State Responsibility, by Roda Verheyen)' (2006) 75 Nordic JIL 357, 8, noting that 'a customary rule as a primary obligation has the disadvantage of the rule's vagueness, which makes it difficult to determine its exact content'.

63. See in particular the Trail Smelter arbitral award (n 11), requiring that 'the case is of serious consequence', and, generally, Sands and Peel (n 1) at 707-11. 
with regard to climate change. That climate change results in dramatic adverse consequences globally has long been recognized by all states. ${ }^{64}$

Yet, thornier issues relate to the requirement of a causal relation between the wrongful act and the harm. In the law of state responsibility, it is generally considered that the injury needs to be the proximate and foreseeable consequence of the wrongful act, although it does not need to be its direct or determinate consequence. ${ }^{65}$ In the Naulilaa case, an arbitral panel declared Germany partly responsible for the revolt of several peoples colonized by the Portuguese following German attacks. The panel acknowledged that Germany could not have foreseen the extent of the resulting turmoil in Portugal's colonies, but it considered that Germany should have anticipated that their military intervention, in a land that had recently been colonized by the Portuguese, would bring about redoubtable consequences for the Portuguese conquest. ${ }^{66}$ Consistently, the International Law Commission clarified that the injury only excludes consequences that are "too "remote" or "consequential" to be the subject of reparation' ${ }^{67}$

While the no-harm principle has developed in the context of transboundary environmental damages, the determination of the harm is considerably more challenging when it is mediated by a change in a planetary system such as the climate system. ${ }^{68}$ The consequences of climate change on individuals are not only indirect, but also particularly remote and consequential. How a natural disaster unfolds and, for instance, whether individuals need to migrate largely depends on a range of political, social, economic, demographic and cultural circumstances in the country and communities affected by environmental impacts. ${ }^{69}$ The development of concepts such as adaptation, resilience or disaster preparedness reflects a growing understanding of the contingency of the harm to local circumstances and the existence of policy levers to mitigate this harm, especially over the long term.

Furthermore, the attribution of a physical event to climate change may also be problematic. On the one hand, gradual environmental changes such as sea-level rise, increasing average temperatures, ocean acidification, glacial retreat, land degradation and desertification, and impacts on human health often occur concurrently with many other anthropogenic or natural transformations, and even the statistical 'signal' of climate change is sometimes difficult to identify. ${ }^{70}$ On the other hand, despite scientific evidence that climate change causes a statistical increase of the frequency of certain

64. See eg UNFCCC (n 5) 2nd recital and art 2.

65. See eg Bernhard Graefrath, 'Responsibility and Damages Caused: Relationship between Responsibility and Damages' (1985) 184 Rec des cours 9, 95; Institut de Droit International, 'Responsibility and Liability under International Law for Environmental Damage' (1998) 37 ILM 1474, art 3, according to which '[t]he mere unforeseeable character of an impact should not be accepted in itself as an exemption'.

66. Responsabilité de l'Allemagne à raison des dommages causés dans les colonies portugaises du sud de l'Afrique (Portuval v Germany), II UNRIAA 1011, 1032 (sentence sur le principe de la responsabilité, 1928) [hereinafter 'Naulilaa case'].

67. ILC Articles, commentary under art 31, para 10. See also Naulilaa case, (n 66) at 1031. 68. See in particular Zahar (n 3) at 229.

69. See generally Pardeep Pall et al., 'Anthropogenic Greenhouse Gas Contribution to Flood Risk in England and Wales in Autumn 2000' (2011) 470 (7334) Nature 382, 385.

70. Christopher B Field et al. (n 16) at 4, noting in particular that 'only a few recent species extinctions have been attributed to climate change'; that 'the worldwide burden of human illhealth from climate change is relatively small compared with effects of other stressors'; and concluding that 'differences in vulnerability and exposure ... shape differential risks from climate change'. 
extreme weather events (eg cyclones, droughts), ${ }^{71}$ it is impossible to identify individually any such event as a 'consequence' of climate change. ${ }^{72}$ Any given weather event could conceivably 'have occurred by chance in an unperturbed climate', ${ }^{73}$ and, despite changes in probabilities of specific events, it is impossible to make a clear distinction between 'human-caused weather' and 'tough-luck weather'. ${ }^{74}$ Here again, gradual changes in the probability of particular weather events can hardly be distinguished from faster changes in social exposure and vulnerability ${ }^{75}$ and some specialists suggest that the statistical 'signal' of climate change on extreme weather events could not generally be isolated before at least several decades. ${ }^{76}$

Thus, assessing the harm is far more difficult in relation to climate change than in classical cases of transboundary environmental damages. Yet, the difficulty of identifying concrete harms does not negate the existence of harm at a more abstract level. Some societies are clearly impoverished because of climate change. States' unanimous acknowledgment that 'change in the Earth's climate and its adverse effects are a common concern of humankind ${ }^{77}$ and their recognition of the goal of avoiding 'dangerous anthropogenic interference with the climate system' ${ }^{78}$ suggest an analysis of the adverse impacts of climate change as a harm to global atmospheric commons. ${ }^{79}$ At this level of abstraction, the consequences of greenhouse gas emissions are relatively proximate and foreseeable: the relation between greenhouse gas emissions and climate change measured in terms of increase in the global average temperature is almost automatic and relatively predictable. Having recognized the relevance of the no-harm principle in circumstances whereby a state causes harms to the environment of other states or to areas beyond the limits of national jurisdiction (hence including global commons such as the High Seas, Antarctica and Outer Space), there is no apparent ground not to equally apply the no-harm principle to circumstances where one, several, or even all states are causing serious harm to global atmospheric commons, which, states recognized, are equally of common concern.

71. See Simon K Allen (n 15) at 8, 13, et passim; Lisa V Alexander et al., Summary for Policymakers, in D Qin et al. (eds), Climate Change 2013: The Physical Science Basis (Working Group I Contribution to the Fifth Assessment Report of the Intergovernmental Panel on Climate Change) 3 (CUP, Cambridge 2014) 5, 20, et passim.

72. On the development of a science of probabilistic attribution and its limitations, see Mike Hulme, 'Attributing Weather Extremes to "Climate Change": A Review' (2014) 38 Progress in Physical Geography 499. See also Christian Huggel et al., 'Loss and Damage Attribution' (2013) 3(8) Nature Climate Change 694.

73. Dáithí A Stone and Myles R Allen, 'The End-to-End Attribution Problem: From Emissions to Impacts' (2005) 71(3) Climatic Change 303.

74. Mike Hulme, Saffron J O'Neill and Suraje Dessai, 'Is Weather Event Attribution Necessary for Adaptation Funding?' (2011) 334(6057) Science 764, 764.

75. See Lisa V Alexander et al. (n 71) at 9; Laurens M Bouwer, 'Have Disaster Losses Increased Due to Anthropogenic Climate Change?' (2010) 92(1) Bulletin of the American Meteorological Society 39.

76. See in particular Laurens M Bouwer, 'Projections of Future Extreme Weather Losses Under Changes in Climate and Exposure' (2013) 33 Risk Analysis 915, noting that 'the signal from anthropogenic climate change is likely to be lost among the other causes for changes in risk, at least during the period until 2040'.

77. UNFCCC (n 5) first recital.

78. Ibid art 2.

79. On the concept of global commons, see eg Sands and Peel (n 1) at 12. 


\subsubsection{The content of states' obligations}

Having broadly defined the harm resulting from climate change, it remains to define the content of states' obligations in relation to this harm. Yet, because the no-harm principle stems from customary international law and has only been implemented in a few jurisdictional decisions, its nature and scope remains largely indeterminate.

The main question here relates to the standard of care applicable to the obligation of states to ensure that activities within their jurisdiction do not cause cross-boundary environmental damage. The standard of care determines not only the scope of present obligations, but also the historical span of the injury. If the no-harm principle only prevents negligence, states cannot be held responsible for the consequences of excessive greenhouse gases emitted before the establishment of a scientific consensus that the climate was changing because of greenhouse gas emissions. ${ }^{80}$ Alternatively, a regime of strict liability would suggest that states could bear responsibility for excessive emissions since the beginning of the industrial era. Besides, whether certain greenhouse gas emissions necessary to the development of a modern economy could be excused also depends on the qualification of the standard of care.

The most coherent interpretation of the no-harm principle is as a due diligence obligation rather than as strict liability. This conclusion is suggested by the wording of the no-harm principle in the Stockholm and Rio Declarations as an obligation 'to ensure ...' - a phrase that has often been used to suggest due diligence rather than strict liability. ${ }^{81}$ In the same sense, the International Court of Justice in the Pulp Mills case considered that a state has the obligation 'to use all the means at its disposal in order to avoid activities which take place in its territory, or in any area under its jurisdiction, causing significant damage to the environment of another State' ${ }^{82}$ The OECD's Environment Committee also identified a 'custom-based rule of due diligence imposed on all states in order that activities carried out within their jurisdiction do not cause damage to the environment of other states' ${ }^{83}$ Finally, the International Law Commission stated, regarding transboundary harms from hazardous activities, that 'the obligation of the State of origin to take preventive or minimization measures is one of due diligence'. ${ }^{84}$

Yet, there is no clear legal basis to determine accurately the level of due diligence. According to a resolution of the International Law Association on the legal principles relating to climate change, the no-harm principle entails a due diligence obligation for states to 'take all appropriate measures to anticipate, prevent or minimise the causes

80. This consensus appeared progressively from the early 1960s to the late 1980 s. See Spencer R Weart, The Discovery of Global Warming (2nd edn, Harvard University Press, Cambridge, MA 2008); Spencer Weart, 'The Development of the Concept of Dangerous Anthropogenic Climate Change', in John S Dryzek, Richard B Norgaard and David Schlosberg (eds), The Oxford Handbook of Climate Change and Society (OUP, Oxford 2011) 67.

81. See Responsibilities and obligations of States sponsoring persons and entities with respect to activities in the Area (advisory opinion, 2011) ITLOS Reports 10, para 112.

82. Pulp Mills on the River Uruguay (n 14) para 101 [emphasis added].

83. See ECD, Report by the Environment Committee, Responsibility and Liability of States in Relation to Transfrontier Pollution 4 (1984), cited in Sands and Peel (n 1) at 713.

84. Prevention of Transboundary Harm from Hazardous Activities, draft articles adopted by the International Law Commission, UN Doc A/56/10, Commentary on art 3, para 7 (2001). See also The Law of the Non-Navigational Uses of International Watercourses, draft articles adopted by the International Law Commission, in UN Doc A/39/10, Commentary on art 7, para 4 (1994). 
of climate change, especially through effective measures to reduce greenhouse gas emissions' ${ }^{85}$ This provision remains inevitably vague. The International Tribunal for the Law of the Sea (ITLOS) once considered that the standard of due diligence obligations of environmental protection is 'a variable concept', contingent on scientific or technologic knowledge of the risks involved in the activity, among other factors. ${ }^{86}$ As climate science progressively establishes a grimmer picture of the consequences of greenhouse gas emissions and as insufficient response measures are adopted, the failure of a state to take appropriate measures becomes, so to speak, increasingly wrongful.

On the other hand, the concept of necessity (état de nécessité) could preclude the wrongfulness of certain acts. ${ }^{87}$ A compelling but somewhat trivial case of necessity relates to the relatively negligible emissions of greenhouse gases produced through human respiration. More consequential arguments could however attempt to justify the emissions resulting from a certain level of industrialization, arguably necessary, if not directly, to human survival, at least to human development. This line of legal arguments parallels the moral distinction suggested by Henry Shue between subsistence emissions and luxury emissions. ${ }^{88}$ Admittedly, the no-harm principle alone cannot suffice to define the concrete modalities of such a thorny distinction (which level of human development do we really need?). Rather than a dichotomy, necessity would require, in this context, a more sensitive analysis of proportionality through a balancing of interests, ${ }^{89}$ with possibly a gradual justification for different levels of greenhouse gas emissions. Although there clearly is no magic formula and a number of inherently political choices are involved, 'necessary' emissions should arguably be defined on a per capita basis and there might be a need to take certain other national circumstances into account. ${ }^{90}$

Another interesting question relates to the geographical scope of states' obligations under the no-harm principle. The textbook case of the no-harm principle concerns activities carried out within the territory of a state. But what about a state's control over activities taking place outside its territory? Extraterritorial obligations could impose certain obligations on states in relation to the overseas activities of domestic

85. ILA (n 3) art 7A(2) [emphasis added].

86. ITLOS (n 81) para117.

87. See eg Articles on State Responsibility (n 25) art 25; Gabčíkovo-Nagymaros Project (Hungary/Slovakia) [1997] ICJ Rep 7, [51]-[52]; Sarah Heathcote, 'Circumstances Precluding Wrongfulness in the ILC Articles on State Responsibility: Necessity', in James Crawford et al. (eds), The Law of International Responsibility (OUP, Oxford 2010) 491.

88. Henry Shue, 'Subsistence Emissions and Luxury Emissions' (1993) 15 Law \& Policy 39, 39.

89. See for instance Robert Q Quentin-Baxter, Second report on international liability for injurious consequences arising out of acts not prohibited by international law, UN Doc A/ CN.4/346, para 67 (1981), concluding that '[t]he equipoise of the two halves of Stockholm Principle 21 evokes a balancing of interests that cannot be attained in terms of the simple dichotomy between right and wrong'. See also Affaire du Lac Lanoux (1957) XII UNRIAA 281, para 23: 'France is entitled to exercise her rights; she cannot ignore Spanish interests. Spain is entitled to demand that her rights be respected and that her interests be taken into consideration'.

90. For instance, populations living in a cold climate may need more greenhouse gas emissions for heating, and populations living in vast, sparsely populated territories may need more emissions for transportation, in order to achieve the same degree of human development. The availability of sources for renewable energy may also be a relevant element. 
companies or overseas production for domestic consumption. ${ }^{91}$ By contrast to a clear attachment to the state's territory in the Trail Smelter arbitral award, subsequent references to the no-harm principle - including the Stockholm and Rio Declarations as well as the ICJ's 1996 Advisory Opinion on the Legality of the Threat or Use of Nuclear Weapons - have repeatedly referred to activities within the state's 'jurisdiction' or 'control'. 92 A similar language used in human rights treaties has increasingly been construed as imposing certain extraterritorial obligations on states. ${ }^{93}$ Likewise, one might argue that a state which is able to control excessive greenhouse gas emissions abroad without affecting the jurisdiction of other states should bear some due diligence obligation to do so. There could accordingly be circumstances whereby two states have a due diligence obligation with regard to the same activity, respectively on the grounds of territorial sovereignty and control. ${ }^{94}$

\subsection{Secondary obligations to cease the wrongful act}

Invoking the no-harm principle suggests that the failure of a state to prevent excessive greenhouse gas emissions within its jurisdiction constitutes an international wrongful act unless it can be justified by circumstances precluding wrongfulness. This internationally wrongful act of a state entails certain secondary obligations. While the present subsection examines the relevance of the obligation to cease the wrongful act, if it is continuing, a following subsection discusses remedial obligations.

At first sight, the application of the obligation to cease a continuing wrongful act is relatively straightforward. The failure of a state to prevent harmful activities within its jurisdiction is a continuing act of omission, which must be ceased through the adoption of appropriate policies. ${ }^{95}$ This means that states must fulfil their due diligence obligation of preventing excessive greenhouse gas emissions. Immediate cessation is unrealistic if compliance requires changes to some of the foundations of modern industrial economies, largely built on the combustion of fossil fuels. The obligation to cease a continuing wrongful act should not be construed in support of unrealistic demands: on the contrary, its interpretation has always been flexible, attentive to the

91. An extensive economic literature argues in favour of consumption-based rather than production-based inventories of greenhouse gas emissions to combat carbon leakage and to reduce effects on competition between developed and developing states. See eg Dieter Helm, Cameron Hepburn and Giovanni Ruta, 'Trade, Climate Change, and the Political Game Theory of Border Carbon Adjustments' (2012) 28 Oxford Review of Economic Policy 368; Roland Ismer and Karsten Neuhoff, 'Border Tax Adjustment: A Feasible Way to Support Stringent Emission Trading' (2007) 24 Eur J Law \& Econ 137; Glen P Peters, 'From Production-Based to Consumption-Based National Emission Inventories' (2008) 65 Ecological Econ 13; John Barrett et al., 'Consumption-Based GHG Emission Accounting: A UK Case Study' (2013) 13 Climate Policy 451; Christopher L Weber et al., 'The Contribution of Chinese Exports to Climate Change' (2008) 36 Energy Policy 3572; Glen P Peters et al., 'Growth in Emission Transfers via International Trade from 1990 to 2008' (2011) 108 Proceedings of the National Academy of Sciences of the United States 8903.

92. Stockholm Declaration (n 12) principle 21; Rio Declaration (n 5) principle 2; Legality of the Threat or Use of Nuclear Weapons (n 14) para 29.

93. See discussions in Marko Milanovic, Extraterritorial Application of Human Rights Treaties: Law, Principles, and Policy (OUP, Oxford 2011).

94. This hypothesis is not unknown in international law. See Articles on State Responsibility (n 25) art 47; Certain Phosphate Lands in Nauru (n 56) para 48; Corfu Channel (n 10) at 22-3. 95. Articles on State Responsibility (n 25) art 30. 
legitimate interests of the parties, in particular in the cases concerning the no-harm principle. In such cases, as Xue Hanqin noted, 'absolute cessation of damage is often not feasible'. ${ }^{96}$ Jurisdictional applications of the no-harm principle have usually led to a balancing of interests rather than to an absolute duty of cessation, which would often have been impossible to fulfil or, at least, impossible to impose on the parties. ${ }^{97}$ For instance, the Arbitral Tribunal in the Trail Smelter case noted:

It would not be to the advantage of the two countries concerned that industrial effort should be prevented by exaggerating the interests of the agricultural community. Equally, it would not be to the advantage of the two countries that the agricultural community should be oppressed to advance the interest of industry. ${ }^{98}$

The drastic consequences of the obligation of cessation of a continuing wrongful act can be mitigated in different ways. For instance, the Arbitral Tribunal in the Trail Smelter case defined a relatively detailed regime of control. ${ }^{99}$ In another context where cessation requires complex policy changes, the Understanding on Rules and Procedures Governing the Settlement of Disputes of the World Trade Organization Agreement provides for a 'reasonable period of time', which may extend to 15 months or more, for states to comply with a decision of the WTO adjudicating body 'if it is impracticable to comply immediately'. ${ }^{100}$ Beyond the trade regime, Olivier Corten argued that force majeure could justify a similar grace period for compliance. ${ }^{101}$ Necessity could similarly justify progressive compliance in relation to climate change.

\subsection{Secondary obligation to make reparation}

Remedial obligations are certainly the most controversial aspect of the no-harm principle in the context of climate change. As Robert Quentin-Baxter noted in a report to the International Law Commission, '[a]ny tendency to insist that all transboundary harm is wrongful, or automatically compensable in accordance with optimal standards, causes justified alarm and impedes human progress'. ${ }^{102}$ Fears of excessive claims for compensation have been determinant in the exclusion of the no-harm principle by industrial states.

The analysis that follows flags certain apparent difficulties in identifying the putative beneficiaries of remedial obligations, given in particular that the harm caused by climate change affects the global commons rather than any specific states (3.3.1). Yet, these difficulties (and some of the political objections to the no-harm principle) are mitigated if the remedial obligation is conceived - as I argue it should be - as a general obligation to apologize and make amends instead of a strict obligation to make full reparation (3.3.2).

96. Hanqin Xue, Transboundary Damage in International Law (CUP, Cambridge 2002) 147.

97. No 13 of February 17, 1934, from the Prime Minister and Secretary of State for External Affairs of Canada, RB Bennett, to the American Minister in Canada, WD Robbins, reproduced in I Foreign Relations of the United States 906 (1934). The Trail Smelter case was of great economic importance to the Canadian province of British Columbia.

98. Trail Smelter arbitral award (n 11) at 1939.

99. See ibid at 1966-78.

100. 1869 UNTS 401, art 21(3) (1994).

101. Olivier Corten, 'The Obligation of Cessation', in James Crawford et al. (eds), The Law of International Responsibility (OUP, Oxford 2010) 548.

102. Robert Q Quentin-Baxter (n 89) para 43. 


\subsubsection{The beneficiaries of restorative obligations}

As noted before, it is practically impossible to attribute specific individual harms to climate change. Instead, the harm generated by excessive greenhouse gas emissions - and the 'injury' to which the remedial obligation of the responsible parties relate - is best conceived as harm to the global commons. ${ }^{103}$ This observation begs another question: who is entitled to reparation, if the harm is suffered by the international community as a whole? Relieving the responsible parties from their remedial obligations because the harm does not have a proximate consequence on any legal person would hinder the objectives of state responsibility for internationally wrongful acts, namely to deter the commission of such acts and to remedy their harmful consequences. ${ }^{104}$ The law of state responsibility, as codified by the International Law Commission, does not exclude the possibility of reparation for the breach of an obligation owed to the international community as a whole. ${ }^{105}$ Certain forms of reparations do not require the precise identification of a beneficiary: such is the case of restitution (although an unlikely remedy in the case of climate change) and certain forms of satisfaction such as an acknowledgment of wrongdoing or some forms of apologies. Compensation, by contrast, requires the identification of a recipient.

International action on climate change adaptation and negotiations on loss and damage have consistently focused on the harms suffered by individuals and communities. ${ }^{106}$ This focus is problematic. While harms are always (more or less directly) suffered by individuals, international law is based on the assumption that the state suffers an injury when its nationals are harmed. ${ }^{107}$ Exceptions have been made to this principle, including in remedying to wrongful acts of states, but only in legal fields where there is usually a clear and direct causal relation between a state's conduct and an individual's harm, most notably through the development of regional human rights jurisdictions assessing individual requests. ${ }^{108}$

103. See Mayer (n 42) section III.A.1.

104. See Articles on State Responsibility (n 25) Commentary under art 1, para 3.

105. See ibid. art 48(2)(b), allowing states to claim from the responsible state '[p]erformance of the obligation of reparation in accordance with the preceding articles, in the interest of the injured State or of the beneficiaries of the obligation breached'. The Commentary of this article (para 12) recognizes that this provision 'involves a measure of progressive development, which is justified since it provides a means of protecting the community or collective interest at stake'. 106. See eg J Ayres et al. (eds), Community-Based Adaptation to Climate Change: Scaling It Up (Routledge, New York 2014); Community-based Adaptation to Climate Change (International Institute for Environment and Development, 2009); Maarten K van Aalst, Terry Cannon and Ian Burton, 'Community Level Adaptation to Climate Change: The Potential Role of Participatory Community Risk Assessment' (2008) 18 Global Environmental Change 165.

107. See in particular Mavrommatis Palestine Concessions (Greece v United Kingdom), PCIJ, Ser A No 2, 12 (Objection to the Jurisdiction of the Court, Judgment of 30 August 1924), stating that a state exercising diplomatic protection is 'in reality asserting its own rights'. See also Articles on State Responsibility (n 25) Commentary under art 36, para 16.

108. Another example is that of certain war reparation mechanisms, in particular in the controversial case of the UN Compensation Commission. The possibility for a state to file claims 'on behalf of its nationals' was also contemplated by the Agreement between Ethiopia and Eritrea, 2138 UNTS 93, art 5(8) (2000), but it was not implemented by either party. Moreover, the arbitral commission formed at this occasion considered that the procedure of the UN Compensation Commission was contingent on exceptional circumstances and could not form a precedent in conceiving war reparations. See Eritrea-Ethiopia Claims Commission, decision No. 7, paras 28-32 (Guidance Regarding Jus ad Bellum Liability, 27 July 2007). 
Beyond the question of consistency with the legal fiction of the state, international action on adaptation undermines the independence of recipient states by justifying virtually unlimited interference by multilateral or (more often) bilateral funding agencies. ${ }^{109}$ Unlike restitution or compensation, adaptation supposes a political vision of what a community should become. ${ }^{110}$ Adaptation policies are more often than not intrinsically linked with the formulation of development policies, a matter which lies at the core of a state's sovereign rights. ${ }^{111}$ Therefore, the repeated calls for a 'country-driven approach'112 to adaptation cannot suffice to protect the sovereignty of states when funding remains imposed on multiple conditions, ranging from the mere requirement that the use of funds for adaptation purposes be demonstrated, to perhaps more specific policies on how 'climate migration' should be managed. The history of European colonialism must remind us that such systematic interference, however justified by noble intentions, leads to the imposition of a political agenda and economic priorities detrimental to the populations concerned.

Instead, a principled approach of responses to climate change would require that the states are identified as the intended beneficiaries of reparation. Naturally, it remains difficult to fairly determine the harm that could be attributed to any individual state. It needs to be rehearsed that in no case should this difficulty lead to the outright rejection of remedial obligations, for a rough assessment of justice is certainly preferable to no justice at all. ${ }^{113}$ Advances in climate modelling could provide a better understanding of slow-onset environmental changes and changes in the probability of extreme weather events attributable to climate change, which could allow a rough estimation of the respective harms suffered by different states. Even such a rough estimate could be sufficient if, as is suggested below, remedial obligations do not consist in an obligation to make full reparation. In states' practice, many disputes are in fact solved by lump-sum agreements adopted through state negotiations (in particular regarding the nationalization of foreign properties), ${ }^{114}$ in other cases, the quantum of compensation has often been assessed on somewhat approximate grounds. ${ }^{115}$

109. See eg Barbara Buchner et al., Global Landscape of Climate Finance 2014 (Climate Policy Initiative, 2014).

110. See eg Mark Pelling, Adaptation to Climate Change: From Resilience to Transformation (Routledge, London 2011) 3, claiming that '[c]limate change adaptation is an opportunity for social reform'.

111. See eg Declaration on the Right to Development, General Assembly resolution 41/128 (1986), art 2(3).

112. See eg UNFCCC (n 5) art 4(1)(b); Cancun Agreements (n 5) para 12.

113. See Opinion in the Lusitania Cases (United States v Germany) (1923) VII UNRIAA 35, 36: 'In many tort cases, including those for personal injury and for death, it is manifestly impossible to compute mathematically or with any degree of accuracy or by the use of any precise formula the damages sustained ... This, however, furnishes no reason ... why he who has suffered should not receive reparation therefor measured by rules as nearly approximating accuracy as human ingenuity can devise'.

114. See eg Richard B Lillich and Burns H Weston, International Claims: Their Settlement by Lump Sum Agreements (Transnational Publishers, New York, 1975); Burns H Weston, David J Bederman and Richard B Lillich, International Claims: Their Settlement by Lump Sum Agreements, 1975-1995 (Transnational Publishers, New York 1999).

115. See American Law Institute, Third Restatement of the Law: The Foreign Relations Law of the United States (1987), para 901, reporters' notes, para 4: 'The rules relating to compensation for a violation are unclear in a number of respects'. 


\subsubsection{The extent of restorative obligations}

The single greatest political obstacle to consideration of the no-harm principle in conjunction with climate change relates to the belief that any wrongful act of a state creates an obligation to make full reparation at all costs. In this sense, the Articles on State Responsibility of the International Law Commission state that a responsible state 'is under an obligation to make full reparation for the injury caused by the internationally wrongful act'. ${ }^{116}$ Yet, this façade of legal determinism conceals long-lasting debates ${ }^{117}$ and the existence of the consistent practice of states satisfying themselves with less-than-full reparation in cases where full reparation would not serve the interests of international justice or would raise unrealistic expectations which could imperil international peace and security. It is clearly the case with regard to climate change that the requirements of justice far exceed the limitations of international politics. ${ }^{118}$ A second-best principled regime taking political constrains into consideration should be preferred to no principled regime at all.

A brief review of the deliberations of the International Law Commission on state responsibility reveals more hesitations than the final articles suggest as to the obligation of states to make full reparation. Thus, the fourth report of Special Rapporteur García Amador on international responsibility in 1959 insisted on the 'general' nature of the principle of adequate reparation, in the context of expropriations, 'because there may be cases and situations in which compensation which does not cover the full value of the expropriated property must be regarded as valid and effective'. ${ }^{119}$ Likewise, during the discussions of an article on full reparation in the mid-1990s, some members of the International Law Commission insisted that some limitations should be established and that 'no form or quantum of reparation should deprive the population of another State of its means of subsistence'. ${ }^{120}$ In particular, these members contended that 'insistence on full reparation could be fraught with consequences for developing countries' ${ }^{121}$ with limited financial capacities. Referring to 'the sad experience of the Versailles settlement which had become one of the causes of the later war', Igor Lukashuk stated that 'experience had shown that [full restitution] was often impossible and even undesirable', and that, in such circumstances,

116. Articles on State Responsibility (n 25) art 31.

117. Some authorities opposed any one-size-fits-all rule. See for instance Lassa Francis Lawrence Oppenheim, International Law: A Treatise (8th edn, Longmans, New York 1955) 352-3: 'The merits and the conditions of the special cases are, however, so different that it is impossible for the Law of Nations to prescribe once and for all what legal consequences an international delinquency should have'; and Christian Tomuschat, 'International Law: Ensuring the Survival of Mankind on the Eve of a New Century' (1999) 281 Recueil des cours 9, 292, noting that the International Law Commission had developed the rule on full reparation on the basis of a review of cases concerning injuries caused to aliens, while '[m] uch less attention was devoted to another fundamental situation of human history, namely war between nations and the settlement of the damages resulting from such tragic events'.

118. Al Gore was reported as stating: ' $\mathrm{t}$ ] he minimum that is scientifically necessary [to combat climate change] far exceeds the maximum that is politically feasible', cited in Bill McKibben, 'Some Like It Hot', The New York Review of Books (5 July 2001).

119. FV Garcia-Amador, Fourth report on State Responsibility, UN Doc A/CN.4/119, para 89 (1959).

120. Summary record, 2454th meeting of the International Law Commission, UN Doc A/CN.4/ SR.2454, para 19 (1996).

121. Sreenivasa Rao, in Summary record, 2314th meeting, UN Doc A/CN.4/SR.2314, para 78 (1993). 
'a system of partial restitution' could be preferable. ${ }^{122}$ Accordingly, the draft articles provisionally adopted at first reading in 1996 excluded measures of reparation that would 'result in depriving the population of a State of its own means of subsistence'. ${ }^{123}$

If this limitation to the obligation to make full reparation was removed from the articles definitely adopted in 2001, it was essentially because states expressed fears that its indeterminacy would create 'avenues for abuses' ${ }^{124}$ or a 'pretext by the wrongdoing State to refuse full reparation'. ${ }^{125}$ Nevertheless, it appears clearly in their remarks that at least some states supported certain limitations to the obligation to make full reparation, although they were concerned by the risks posed by an unclear provision. ${ }^{126}$ In turn, arguments for the withdrawal of this disposition within the International Law Commission had more to do with the general scope of the project ${ }^{127}$ and the relative limitations of the quantum of reparations in international disputes, ${ }^{128}$ than with providing support to an absolute nature of the obligation to make full reparation. A partial agreement among state representatives and ILC members appeared to be that certain flexibilities in the obligation to make full reparation were necessary, but that

122. Summary record, 2392th meeting of the International Law Commission, UN Doc A/CN.4/ SR.2392, para 31 (1995). See also Christian Tomuschat, in ibid. para 37: 'after major disasters like the Second World War and even the aggression by Iraq, it was generally impossible for full compensation to be paid for all of the harm done'. See also Ahmed Mahiou, in Summary record, 2314th meeting of the International Law Commission, UN Doc A/CN.4/SR.2314, para 84 (1993): 'there were indeed exceptions that were not peculiar to restitution in kind'.

123. Draft Articles on the Responsibility of States for Internationally Wrongful Acts adopted by the International Law Commission in first reading, UN Doc A/CN.4/L.528/Add.2, art 42(3) (1996).

124. Comment by the United States, in Comments and observations received by Governments, UN Doc A/CN.4/488 and Add. 1-3, 146 (1998).

125. Comment by Japan, in Comments and observations received by Governments, UN Doc A/CN.4/492, 14 (1999).

126. United Kingdom, in Comments and observations received by Governments, UN Doc A/CN.4/488 and Add. 1-3, 145-6 (1998): 'There might be a separate article stipulating that the right to reparation, in whatever form is to be implemented taking into account, inter alia, the importance of the rule and of the interest protected by it, the seriousness of the breach (and perhaps the degree of negligence or wilful misconduct involved) and the need to maintain international peace and security and to bring about the settlement of international disputes in conformity with principles of international law and justice. The article might then state that when a determination is made as to the precise form that reparation should take, account should be taken of the principle that the form of reparation imposed should not impose a burden on the State making reparation out of all proportion to the benefit that the injured State would derive from some other form of reparation'.

127. See Andrea Gattini, 'The UN Compensation Commission: Old Rules, New Procedures on War Reparations' (2002) 13 Eur J Int'l L 161, 163, arguing that 'the ILC decision to delete the proviso is coherent with its purpose to keep strictly to the exclusive codification of the general secondary rules'.

128. See in particular James Crawford (special rapporteur), in Summary record, 2613th meeting of the International Law Commission, A/CN.4/SR.2613, para 18: 'there was no reason to fear that the requirement to do so would deprive that State of its own means of subsistence. Vastly greater liabilities of States in the context of international debt arrangements were settled every year than ever arose from compensation payments'. See also James Crawford, Third report on State responsibility, UN Doc A/CN.4/507, para 42 (2000): 'there is no history of orders for restitution in the narrow sense, or of the award of damages by way of satisfaction, which have threatened to deprive a people of its own means of subsistence'. 
their inclusion in a general provision within the draft articles raised many difficulties because the conditions for such limitations were not clearly defined. ${ }^{129}$ Possible alternative sources of flexibility were briefly discussed, in particular in relation to circumstances excluding the wrongfulness of the non-payment of reparation such as force majeure or necessity. ${ }^{130}$ Reference was also made to certain domestic legal provisions excluding essential means of subsistence from attachment, ${ }^{131}$ or otherwise limiting responsibility. ${ }^{132}$ It was even proposed that any reference to 'full' reparation be removed. ${ }^{133}$

In cases where the wrongful act of a state causes large-scale harms, examples abound where states negotiated 'incomplete' forms of reparation pragmatically, by putting more emphasis on avoidance of further harms through cessation of a continuing violation, guarantees of non-repetition, restoration of international peace and security, and development of friendly relations, rather than on the punishment of the responsible state. In particular, the spectre of the Versailles treaty fostered a flexible approach to war reparations, whereby 'account was always taken of actual capacity to pay' ${ }^{134}$ As the limited resources of Japan and Germany were duly taken into consideration at the end of World War Two, the objective of complete reparations was usually set aside. ${ }^{135}$ Later on, while many resolutions of the UN General Assembly or Security Council condemned violations of international law, few demanded that the responsible state pays any form of reparation, partly because of uncertainties regarding the scope of remedial obligations. ${ }^{136}$ Even the compensation imposed upon Iraq for the invasion of Kuwait in 1990, channelled through the UN Compensation Commission, a somewhat isolated case standing out for its harshness on the defeated party, was determined with consideration for 'the requirements of the people of Iraq, Iraq's payment capacity ... and the needs of the Iraqi economy'. ${ }^{137}$ Accordingly, compensation was limited to 30 per cent of the annual value of the exports of petroleum and petroleum products from Iraq. ${ }^{138}$

Most recently, the Eritrea-Ethiopia Claims Commission, established to decide claims of injuries following the Eritrean-Ethiopian War, stated that ' $\mathrm{t}] \mathrm{h}$ he Parties' overall economic positions are relevant to determining compensation'. ${ }^{139}$ More

129. James Crawford (special rapporteur), in Summary record, 2613th meeting of the International Law Commission, A/CN.4/SR.2613, para 17.

130. See Alain Pellet, in Summary record, 2614th meeting of the International Law Commission, UN Doc A/CN.4/SR.2614, para 55; Chusei Yamada, in Summary record, 2615th meeting of the International Law Commission, UN Doc A/CN.4/SR.2615, para 44.

131. Chusei Yamada, in Summary record, 2615th meeting of the International Law Commission, UN Doc A/CN.4/SR.2615, para 45.

132. James Crawford, in Summary record, 2634th meeting of the International Law Commission, UN Doc A/CN.4/SR.2634, para 14.

133. See Raul Goco, in Summary record, 2615th meeting of the International Law Commission, UN Doc A/CN.4/SR.2615, para 55.

134. Tomuschat (n 117) at 293.

135. See in particular Treaty of Peace with Japan (1951) 136 UNTS 45, art 14(1); Potsdam Agreement, section IV (1945).

136. See in particular the references cited in Christine D Gray, Judicial Remedies in International law (OUP, Oxford 1987) 216-17.

137. Note of the Secretary-General pursuant to paragraph 13 of his report of 2 May 1991, UN Doc S/22559, para 7 (1991).

138. UNSC Resolution 705, para 2 (1991).

139. Eritrea-Ethiopia Claims Commission, Final Award (17 August 2009) XXVI UNRIAA 631, para 24. 
specifically, the Commission recognized that it could have to 'limit its compensation awards in some manner to ensure that the ultimate financial burden imposed on a Party would not be so excessive, given its economic condition and its capacity to pay, as to compromise its ability to meet its people's basic needs'. ${ }^{140}$ The Commission also considered that the quantum of compensation should take account 'of the low incomes and limited property of most of those affected by the war', ${ }^{141}$ thus sensibly reducing the awards.

Likewise, in numerous domestic instances of transition from authoritarian to democratic regimes, efforts were concentrated on truth, reconciliation and development rather than on reparation. ${ }^{142}$ Instead of full reparation, remedies granted as part of transitional justice often consisted in rehabilitative or symbolic measures such as 'medical and psychological services, health care, educational support, return of property or compensation for loss thereof, but also official public apologies, building museums and memorials, and establishing days of commemoration'. ${ }^{143}$ As Christian Tomuschat notes, 'large-scale damages require other rules than individual cases of wrongdoing'. 144

Investment law is yet another field where systemic derogations to the rule of full reparation have been accepted in cases of nationalizations. As Sornarajah notes, ' $[\mathrm{t}]$ here is no indication in modern practice of full compensation ever having been paid as compensation for nationalisation'. ${ }^{145}$ There is, by contrast, an extensive practice of states agreeing to less-than-full compensation, in particular through hundreds of lump-sum agreements. ${ }^{146}$ Even investor states like the United States admitted that (undefined) 'special circumstances' could justify a derogation to full compensation in cases of expropriations. ${ }^{147}$ Whether grounded on moral or purely political considerations, such arrangements show that reparation can be negotiated through realistic arrangements.

Technological advances make it possible for negligence to result in large-scale environmental damages that may far exceed the financial capacities of responsible states, and where full reparation would be inopportune. ${ }^{148}$ Such is the case of excessive greenhouse gas emissions, which resulted first from states' inadvertence, then from their negligence, and increasingly from their gross negligence. In such a context, the most urgent remedy does not consist in any form of compensation, ${ }^{149}$ but in an

140. Ibid para 22.

141. Ibid para 27.

142. See Priscilla B Hayner, Unspeakable Truths: Transitional Justice and the Challenge of Truth Commissions (2nd edn, Routledge, New York 2011).

143. Guidance note of the Secretary-General: United Nations Approach to Transitional Justice, 8 (March 2010).

144. Tomuschat (n 117) at 293.

145. M Sornarajah, The International Law on Foreign Investment (CUP, Cambridge 2010) 417.

146. See generally Lillich and Weston (n 114); Weston, Bederman and Lillich (n 114).

147. American Law Institute, Second Restatement: The Foreign Relations Law of the United States, para 188(2): 'In the absence of the conditions specified in Subsection (1), compensation must nevertheless be equivalent to full value unless special circumstances make such requirement unreasonable'; and Explanatory Note (c): 'The law is not settled as to what special circumstances may make the requirement of full value unreasonable'.

148. Tomuschat (n 117) at 296-7.

149. By analogy, following the nuclear accident of Chernobyl in 1986, several states reserved their right to claim reparation but did not do so, feeling 'that priority should be given, in the wake of the Chernobyl accident, to endeavors of another nature'. Correspondence with the 
explicit admission by industrial states that excessive greenhouse gas emissions constitute a wrongful act with grave consequences entailing their responsibility. Remedies taking place in the symbolic sphere, ranging from an apologetic posture, to a policy of education, ${ }^{150}$ memory and commemoration, could raise awareness and spur changes in public support for necessary reforms by questioning an unsustainable model of development. Such symbolic measures will unquestionably fuel demands for compensation or other forms of North-South finance, and, indeed, an admission of wrongdoing could not appear sincere unless it comes along with certain measures of amends. These measures, however, could be far from full reparation.

\section{CONCLUSION}

Climate change is the most important case of anthropogenic cross-boundary environmental harm, but 25 years of international negotiations on climate change have given little consideration to the no-harm principle. Yet, the responsibility of states for causing harm to the environment of other states is not a negotiable concept: it is an indispensable corollary of the structures of today's international legal order. States cannot be equal and sovereign, yet knowingly cause harms to others' environment - harms that could go all the way to denying the very existence of some low-lying small island developing states. Admittedly, powerful states can oppose the application of the noharm principle, but they cannot ignore the cost of this denial of justice: the erosion of the trust that populations and states' leaders have progressively placed in international law as an instrument for the construction of a better world rather than a tool of domination. This loss of trust, in turn, hinders international cooperation on climate change: why would a population commit to costly climate change mitigation policies if it is unsure whether other states will implement similar policies, and whether, consequently, they could draw significant benefits from climate change mitigation? Why should a nation not attempt to free-ride on the efforts made by other nations if it does not believe that justice should guide international relations? Successful international cooperation against climate change requires more international socialization, not less, and trust requires actions that are broadly consistent with principles largely considered as just. The no-harm principle is one of these principles, and arguably the most relevant one to the overall architecture of international responses to climate change.

Legal scholars have a role to play in affirming the relevance of international law's principles in response to climate change, thus preparing arguments for successful international negotiations. The greatest impediment to the political acceptability of the no-harm principle relates to a misunderstanding relating to the consequences of the no-harm principle, in particular regarding the ambit of remedial obligations. International jurisdictions are unlikely to be permitted to take substantive decisions in the

Swedish Embassy in London, 10 December 1987, cited in Philippe Sands, Chernobyl: Transboundary Nuclear Air Pollution (CUP, Cambridge 1988) 27. The collapsing state of the economy of the USSR in the late 1990s probably made such claims much less attractive.

150. Education is mentioned in UNFCCC (n 5) art 6(a)(i); Kyoto Protocol (n 5) art 10(e); and in a series of decisions, such as decision -/CP.20, The Lima Ministerial Declaration on Education and Awareness-raising (2014). However, these measures only aim at favouring adaptation and put no emphasis on responsibilities. 
matter. Therefore, international law scholars need to define more nuanced, more realistic, hence more relevant understandings of the responsibilities of states whose failure to regulate domestic activities has had a dangerous impact on our climate system. International law should not be construed in rigid ways that suggest unrealistic obligations: an obligation to make full reparation, in particular, is a dangerous chimera in the context of climate change. The responsibility of states for excessive greenhouse gas emissions needs to be conceived in ways that advance a transition towards more sustainable societies conducive to international peace and security, not in favour of a revanchist utilization of international law. The no-harm principle is relevant, but it needs to be adapted, taking the specific challenges arising from climate change into account, in order to pursue, through international cooperation, the objective of solving the international problems of our time. 